\section{Chrif Elboubakraoui}

Assistant

University of Moulay Ismail Faculty of Science and Technology

Errachidia

Morroco

\section{Seddik Bri}

Full Professor

University of Moulay Ismail Superior School of Technology

Meknes

Morroco

Jaouad Foshi

Full Professor University of Moulay Ismail Faculty of Science and Technology Errachidia Morroco

\section{Electromagnetic Properties of Polymer Composites $\mathrm{CO}_{52} \mathrm{Cr}_{22} \mathrm{Ni}_{10} \mathrm{~W}_{7,5} \mathrm{Fe}_{1,5}$ and $\mathrm{Fe}_{59} \mathrm{Cr}_{21,5} \mathrm{Ni}_{7} \mathrm{Si}_{1} \mathrm{Mn}_{10}$ at $\mathrm{Ku}$ Band}

\begin{abstract}
The electromagnetic properties of polymer composites can be obtained by inverting the numerically simulated reflection $S_{11}$ and transmission $S_{21}$. Two composites containing amorphous glass-coated microwire $\mathrm{Co}_{52} \mathrm{Cr}_{22} \mathrm{Ni}_{10} \mathrm{~W}_{7,5} \mathrm{Fe}_{1,5}$ and $\mathrm{Fe}_{59} \mathrm{Cr}_{21,5} \mathrm{Ni}_{7} \mathrm{Si}_{1} \mathrm{Mn}_{10}$ are investigated in $\mathrm{Ku}$ band. The results show that the imaginary part of permittivity is quite weak, and can be considered as zero, which means that there is no dielectric loss. It is shown that the decrease in the spacing between the inclusions strongly affects the magnetic response in comparison with the dielectric response of the two composites, which is characterized by a ferromagnetic resonance peak FMR. We also present an investigation related to an electromagnetic radiation absorber for a preselected frequency range between 12 and $18 \mathrm{GHz}$. With the increase of microwire spacing, the minimum reflection loss decreases firstly and then increases, and shifts towards lower frequency band.
\end{abstract}

Keywords: Polymer composites, Electromagnetic properties, Ferromagnetic resonance, Reflection.

\section{INTRODUCTION}

The interest of amorphous magnetic materials has persisted for several years for the study of their structural, magnetic and kinetic properties. On the one hand, it had been established that these materials exhibit unique physical properties. Consequently, they have found wide application in nano and microelectronic, at relatively low cost of production [1-2]. On the other hand, this importance was caused by the progress of innovative materials and composites, derived on the base of the amorphous microwires. The quest for efficient tunable sensing and frequency-agile materials has led to the investigation of polymer-based composites containing such microwires, where a variety of emerging functionalities have been reported [1]. Several recent papers have exposed the usefulness of metamaterials that produce having negative permittivity and negative permeability [3-4]. The proposed extraction technique was used to extract relative material parameters for different analytical examples. We tested the extraction method for permittivity or permeability materials.

\section{THEORY}

The material parameter extraction methods have recently attracted attention in the literature because of the growing interest in metamaterials and the need to characterize the electromagnetic properties of these complex synthetic materials. The Nicholson-Ross-Weir

Received: May 2017, Accepted: June 2017

Correspondence to: My Chrif Elboubakraoui

Faculty of Science and Technology,

BP 509 Boutalamine, Errachidia, Morroco

E-mail: charif2060@gmail.com

doi: doi: $10.5937 /$ fmet1704678E

(C) Faculty of Science and Technology, Errachidia. All rights reserved
(NRW) procedure is an extraction technique based on measurements (or numerical simulations) of the reflection and transmission coefficients of a planar material sample. This procedure yields an explicit expression for permittivity and permeability as a function of the measured S-parameters.

For quasi-TEM transmission lines (and obviously for rectangular waveguide measurements) $\lambda \mathrm{c} \rightarrow \infty$. The parameters $S_{11}$ at the air-material interface and $S_{21}$ through the material can be calculated from the scattering parameters taking into account the phase correction due to the separation of the planes 1 and 2 and ports 1 and 2 [5-6].

The reflection coefficient is defined by [7]:

$$
\begin{gathered}
\Gamma=\frac{\eta-\eta_{0}}{\eta+n_{0}}=X \pm \sqrt{X^{2}-1} \text { with }|\Gamma|<1 \\
X=\frac{S_{11}^{2}-S_{21}^{2}+1}{2 S_{11}}
\end{gathered}
$$

where $\eta$ and $\eta_{0}$ are the impedances for the sample and free space, respectively.

The transmission coefficient can be written as:

$$
T=e^{-\gamma d}=\frac{S_{11}+S_{21}-\Gamma}{1-\left(S_{11}+S_{21}\right)}
$$

Phase factor for the wave propagating through the measured material slab with thickness d [6].

Where $\gamma$ is the complex wavenumber.

$$
e^{-\gamma d}=\frac{S_{11}+S_{21}-\Gamma}{1-\left(S_{11}+S_{21}\right) \Gamma}
$$

The difficulty with the aforesaid extraction technique relates to the periodicity of the phase factor 
for the wave propagating through the measured material bloc that causes equation (4) to have an infinite number of roots, that is [6-7].

$$
e^{-\gamma d}=e^{-\alpha d} e^{-j(\beta d-2 m \pi)}
$$

where $\alpha$ and $\beta$ are the attenuation and propagation constants in the measured sample, respectively, and $\mathrm{m}$ is some integer.

$$
\alpha=-\frac{\ln |T|}{d}
$$

The permittivity and permeability can be expressed in terms of $\eta$ and $\gamma$ as given by:

$$
\begin{gathered}
\varepsilon_{\text {eff }}=\frac{\gamma}{j \omega n}=\frac{1+\Gamma}{n^{2}(1-\Gamma)} \sqrt{\frac{\eta^{2}-\left(\frac{\omega_{r}}{\omega}\right)^{2}}{1-\left(\frac{\omega_{r}}{\omega}\right)^{2}}} \\
\mu_{e f f}=\frac{\gamma \eta}{j \omega}=\frac{1+\Gamma}{1-\Gamma} \sqrt{\frac{\eta^{2}-\left(\frac{\omega_{r}}{\omega}\right)^{2}}{1-\left(\frac{\omega_{c}}{\omega}\right)^{2}}}
\end{gathered}
$$

where $\omega$ is the angular frequency and $\omega_{c}$ is the angular cutoff frequency of the transmission line section in which the material sample is positioned.

The microwave properties of materials were evaluated by the reflection loss, and which can be calculated based on complex permeability and complex permittivity. According to the transmission line theory, for a single layer absorbing material backed by a perfect conductor, the input impedance $\left(Z_{\text {in }}\right)$ at the air-material interface is given by [8-10]:

$$
Z_{\text {in }}=Z_{0} \sqrt{\frac{\mu}{\varepsilon}} \tanh \left(i \frac{2 \pi f d}{c} \sqrt{\mu \varepsilon}\right)
$$

where $d$ is the absorber thickness, $Z_{0}$ is the impedance of free space, and $c$ is the velocity of electromagnetic waves in free space. The reflection loss of normal incident electromagnetic wave at the absorber surface is given by:

$$
R L=20 \log \left|\frac{Z_{\text {in }}-Z_{0}}{Z_{\text {in }}-Z_{0}}\right|
$$

The attenuation constant $\alpha$ is the real part of the propagation constant, given by:

$$
\alpha=\operatorname{Re}\left(\frac{i 2 \pi f \sqrt{\mu z}}{c}\right)
$$

\section{RESULTS AND DISCUSSION}

The extraction formulas are then applied to the more complicated planar polymer composite case. Combining the S-parameter comparisons and the extraction procedure results, it is demonstrated that polymers have been designed and fabricated and exhibit the properties predicted by the COMSOL MULTIPHYSICS ${ }^{\circledR}$ simulation.

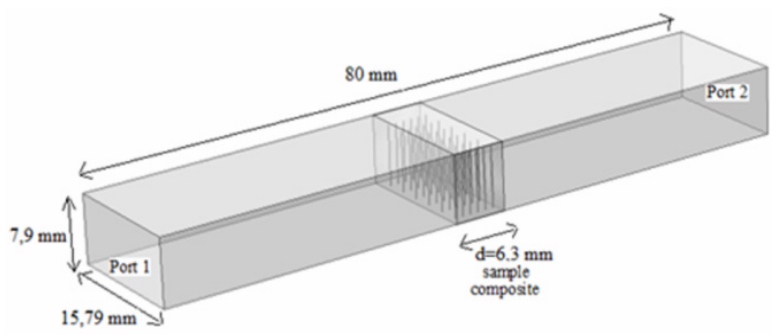

Figure 1. Schematic figure of the rectangular waveguide setup used for extraction of the material parameters in the Ku band

In order to identify the validity of this new approach to simulating the electromagnetic properties of polymer materials, the permittivity and permeability values of $\mathrm{Co}_{52} \mathrm{Cr}_{22} \mathrm{Ni}_{10} \mathrm{~W}_{7.5} \mathrm{Fe}_{1.5}$ and $\mathrm{Fe}_{59} \mathrm{Cr}_{21.5} \mathrm{Ni}_{7} \mathrm{Si}_{1} \mathrm{Mn}_{10}$ were estimated using numerical simulations in the band Frequency $\mathrm{Ku}$. On the one hand, the effect of the spacing between the microfils on the values deduced from the permittivity and the permeability is deduced. On the other hand, the simulated values are discussed with other values obtained from the literature. The two samples used are made of soft magnetic microfilm composite materials, where Cobalt is the main element for $\mathrm{Co}_{52} \mathrm{Cr}_{22} \mathrm{Ni}_{10} \mathrm{~W}_{7.5} \mathrm{Fe}_{1.5}$ (wire 1) and iron is the main element for $\mathrm{Fe}_{59} \mathrm{Cr}_{21.5} \mathrm{Ni}_{7} \mathrm{Si}_{1} \mathrm{Mn}_{10}$ (wire 2).

Amorphous glass-coated ferromagnetic wires having a total diameter is $\mathrm{R}=60 \mu \mathrm{m}$, and the diameter of the core is $\mathrm{r}=10 \mu \mathrm{m}$, which are incorporated into the silicone rubber matrix.
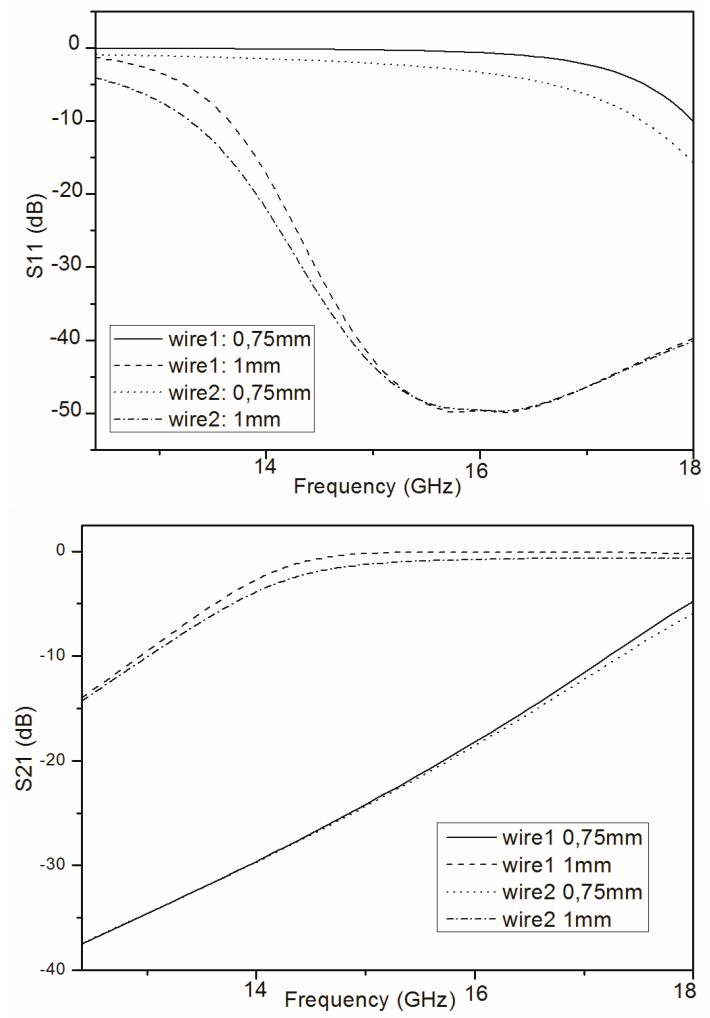

Figure 2. Frequency variations of reflection parameter $S_{11}$ and transmission parameter $S_{21}$ in the $\mathrm{Ku}$ band

Figure 2 shows the frequency dependence of the reflection parameter $S_{11}$ and transmission parameter $\mathrm{S}_{11}$ 
for the two composites taken at different spacing intervals of $0.75 \mathrm{~mm}$ and $1 \mathrm{~mm}$. A comparison between the transmission and reflection spectra reveals that the periodicity of the spacing between wires has a profound impact on the intensity of $S_{11}$ and $S_{21}$ but much less effect on the tunability.

Figure 3 illustrates the evolution of the dielectric permittivity of these polymers as a function of the frequency through the frequency band $\mathrm{Ku}$.
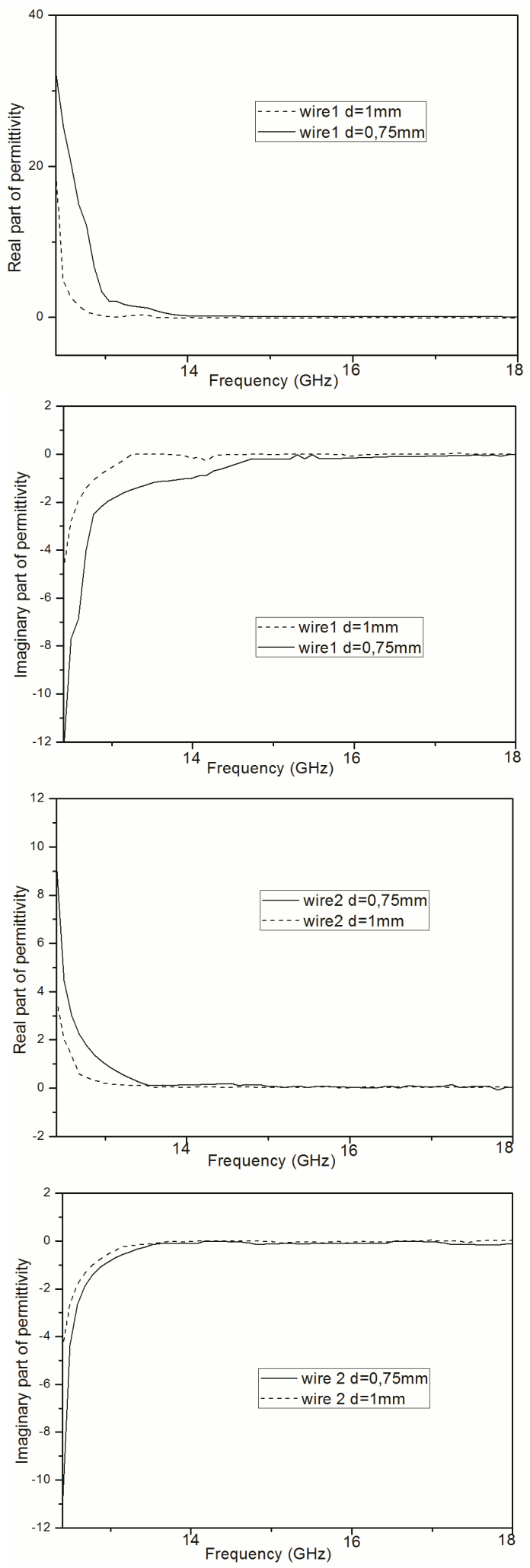

Figure 3. Frequency variation of the real and imaginary part of the effective permittivity in the Ku band
In this series, on the one hand, both composites have similar dielectric dispersion properties. For the evolution of the permittivity as a function of the frequency in the two different conditions of periodicity, the curves are very close since the permittivity is not influenced in a remarkable way except the appearance of a slight increase of the part Real and a small decrease in the imaginary part, which are well displayed at the beginning of each frequency band when the periodicity increases. On the other hand, we notice that the real permittivity quasi-constant on the frequency bands $\mathrm{Ku}$ which spreads up to $18 \mathrm{GHz}$ since the permittivity is not influenced in a remarkable way. The imaginary part begins to increase in value but remains rather weak. This is translated by the conductive nature of the composites which thus increases the effective conductivity of the composite medium. The imaginary part is quite weak, and can be considered as zero, which means that there is no dielectric loss in the resin. Since this work aims at the practical realization of metamaterials, the best possible material will be the one with the highest real permittivity combined with a loss level as low as possible. The material loss level will be characterized by the parameter [11]: $\tan \delta=\frac{\varepsilon^{\prime \prime}}{\varepsilon^{\prime}}$

The frequency evolution of effective permeability of the samples tested in the $\mathrm{Ku}$ band is shown in figure 4.

It shows the dependence of the complex permeability of the composite on the periodicity of the spacing between the amorphous glass-coated microwires. As observed, the influence of the glass-coated amorphous microwire periodicity on the complex permeability is clear. The microwires periodicity decreasing, the distance between the micro-wires decreases and the electromagnetic coupling of the microwaves strengthens [12], which leads to the increase of negative value of the imaginary part. As shown in figure 3, A low-frequency peaks are identified around $13,2 \mathrm{GHz}$ to $14,1 \mathrm{GHz}$ in the both composite containing microwires at zero field. $\mu^{\prime}$ is constant up to the neighbouring resonance frequency, and the frequency at which $\mu^{n "}$ is maximum corresponds to the resonance frequency. The imaginary part of effective permeability is characterized by a ferromagnetic resonance peak FMR, that is to say high magnetic losses. Moreover, at frequencies above the FMR, only evanescent waves in exponential decomposition will be present due to a negative real part of the effective permeability [6], [13].

The dependence of the resonance frequency can be expressed by a simple empirical formula that has been very well analytically explained by Baranov [10], [14]:

$$
f_{F M R}=1.5 \sqrt{\lambda \cdot 10^{6} \frac{1-p^{2}}{1-1.5 p^{2}}}
$$

where $p=\frac{r}{R}$ is the metal-to-total diameter ratio and $\lambda$ is magnetostriction cast microwire $(\mathrm{R}=60 \mu \mathrm{m}, \mathrm{r}=10 \mu \mathrm{m})$. 

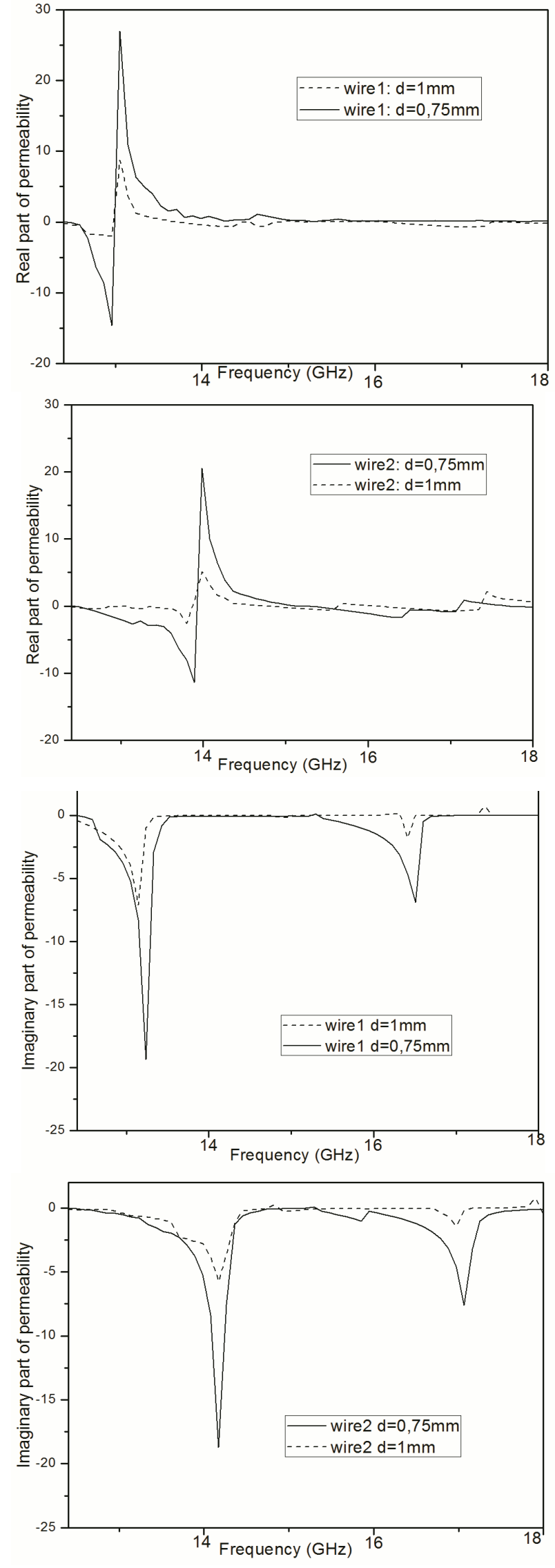

Figure 4. Frequency variation of the real and imaginary part of the effective permeability in the Ku band

The theoretical curve of the FMR frequency as a function of $\mathrm{p}$ according to equation (12) for the two composite wires with different magnetostriction (Table 1 ) is shown in figure 5 .
Table 1. Resonance frequency for the two composite wires studied

\begin{tabular}{|c|c|c|c|}
\hline & $\mathrm{P} \%$ & $\lambda$ & $f_{F M R}(\mathrm{GHz})$ \\
\hline $\begin{array}{c}\text { Wire 1: } \\
\mathrm{Co}_{52} \mathrm{Cr}_{22} \mathrm{Ni}_{10} \mathrm{~W}_{7.5} \mathrm{Fe}_{1.5}\end{array}$ & 17 & $8.5 \cdot 10^{6}$ & 13,1 \\
\hline $\begin{array}{c}\text { Wire 2: } \\
\mathrm{Fe}_{59} \mathrm{Cr}_{21.5} \mathrm{Ni}_{7} \mathrm{Si}_{1} \mathrm{Mn}_{10}\end{array}$ & 17 & $10^{-5}$ & 14,2 \\
\hline
\end{tabular}

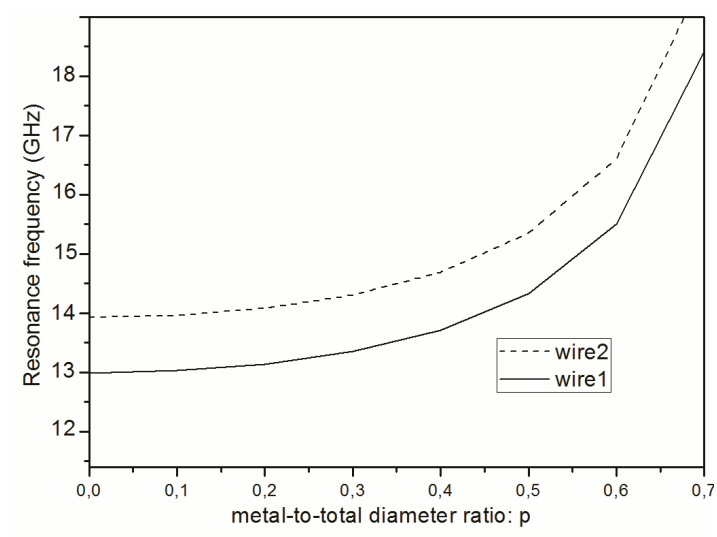

Figure 5. Theoretical curves of FMR frequency as a function of $p$

By using equation (12), the metal-to-total diameter ratio (p) dependence of resonance frequency is calculated for these two wires. The result confirms the role of wire cross-sectional geometry on the natural ferromagnetic resonance frequency and also reveals that the iron-based wires are more suitable for absorption purpose at relatively higher gigahertz frequencies. It should be, however, noted that the resonance frequency can be shifted to higher frequency if a large enough neighbouring field is yielded with a good number of wires added into the absorbing media or tailored wire geometry (Figure 5).
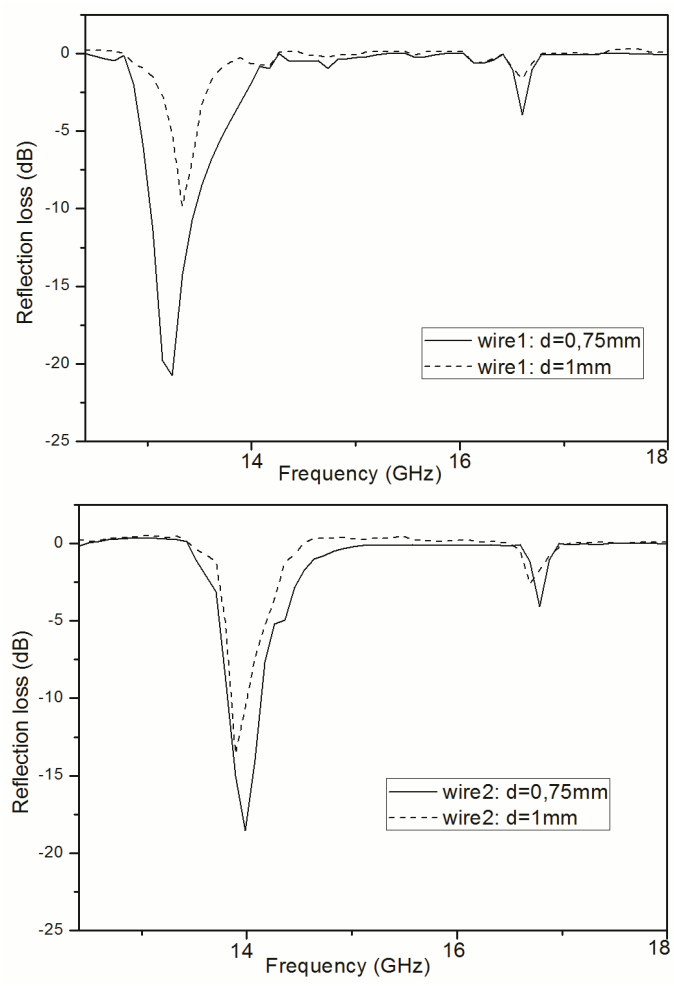

Figure 6. Frequency variation of reflection loss for composites containing long continuous wires 
To shed light on the usefulness of this theory, Radio absorption properties of glass-coated microwires embedded in suitable polymeric matrix have been investigated. Fe-based and Co-based microwires with large and positive magnetostriction exhibit outstanding radio absorption in the microwave range $12,4-18 \mathrm{GHz}$. Typical results are plotted in Figure 6 which shows the simulated reflection loss for the two composite samples with different wire spacing $\mathrm{d}=1 \mathrm{~mm}$ and $\mathrm{d}=0.75 \mathrm{~mm}$.

The curve giving the frequency dependence of the attenuation, with maximum of about $20 \mathrm{~dB}$, is the same as that of the magnetic permeability evolution around the ferromagnetic resonance.

As the spacing increases, the minimum reflection loss decreases first and then increases. For the microwire composite studied $\mathrm{Co}_{52} \mathrm{Cr}_{22} \mathrm{Ni}_{10} \mathrm{~W}_{7.5} \mathrm{Fe}_{1.5}$ (wire 1) and $\mathrm{Fe}_{59} \mathrm{Cr}_{21.5} \mathrm{Ni}_{7} \mathrm{Si}_{1} \mathrm{Mn}_{10}$ (wire 2), the minimum loss frequency position also moves to reduce the frequency. On the one hand, when the spacing is $0.75 \mathrm{~mm}$, the minimum reflection loss is $-21.5 \mathrm{~dB}$ for $\mathrm{Co}_{52} \mathrm{Cr}_{22} \mathrm{Ni}_{10} \mathrm{~W}_{7.5} \mathrm{Fe}_{1.5}$ and $18.25 \mathrm{~dB}$ for $\mathrm{Fe}_{59} \mathrm{Cr}_{21.5} \mathrm{Ni}_{7} \mathrm{Si}_{1} \mathrm{Mn}_{10}$. On the other hand, when the spacing is $1 \mathrm{~mm}$, the minimum reflection loss is -9.85 $\mathrm{dB}$ for $\mathrm{Co}_{52} \mathrm{Cr}_{22} \mathrm{Ni}_{10} \mathrm{~W}_{7.5} \mathrm{Fe}_{1.5}$ and $-13.78 \mathrm{~dB}$ for $\mathrm{Fe}_{59} \mathrm{Cr}_{21.5} \mathrm{Ni}_{7} \mathrm{Si}_{1} \mathrm{Mn}_{10}$. In order to elucidate the contribution of electrical resonance to the absorption, absorbent composite of dielectric material containing the microwires ferromagnetic have been also characterized at high frequency. The microwire can be considered as a small oscillate dipole in the presence of electromagnetic waves. These microwave characterization results of microwire composites obtained in this work were used to design and develop a composite material absorbing electromagnetic waves in broad frequency band. These radiationabsorbing materials (RAM: Radar Absorbent Materials) [15] transform the received electromagnetic energy in another form: heat. They are materials that have specific dielectric or magnetic properties.

In the literature, we find several works that study polymer composites of similar structures. The comparison between the simulated values of permeability for the two composites studied and the measured values for similar structural composites published in the literature [16-19] shows a good agreement between the numerical simulation results and the experimentally measured values. All these results indicate the proposed composite are excellent candidate materials for the microwave sensing and structural interrogation applications.

\section{CONCLUSION}

In this paper, the rectangular method of measuring waveguide transmission is used for the extraction of electromagnetic parameters as a function of the frequency in the $\mathrm{Ku}$ band. The results obtained show that this method is well adapted with the conventional Nicolson-Ross-Weir technique (NRW) to characterize ferromagnetic materials at microwave frequencies. The microwave absorption properties for the two composites studied in the $\mathrm{Ku}$ frequency band are better and they are controllable by adjusting the nature of the molecular inclusions. All these results indicate the proposed composite are excellent candidate materials for the microwave sensing and structural interrogation applications.

\section{REFERENCES}

[1] Luo, Y., Qin, F., Liu, J., Wang, H., Scarpa, F., Adohi, P., Brosseau, C. and Peng, H.X.: Dielectric properties of composites containing melt-extracted co-based microwires, Compos Commun 1, pp. 2024, 2016.

[2] Dinulović, M., Rašuo, B., Dielectric modeling of multiphase composites, Composite Structures, Volume 93, Issue 12, pp. 3209-3215, November 2011.

[3] Ziolkowski, R. W.: Superluminal transmission of information through an electromagnetic metamaterial, Phys. Rev. E, Stat. Phys. Plasmas Fluids Relat. Interdiscip. Top, vol. 63, no. pp. 046604, 2001.

[4] Shalyginaa, E.E., Kharlamovaa, A.M., Shalygina, A.N., Molokanovb, V.V., Umnovb, P.P., Umnovab, N.V. and Chuevab, T.R.: Structural and magnetic properties of "thick" microwires produced by the modernized Ulitovsky-Tailor method, J Magn Magn Mater, pp. 01.056, 2016.

[5] Luukkonen, O. et al:A Stepwise Nicolson-RossWeir-Based Material Parameter Extraction Method", IEEE Antenn. Wireless Propag. Lett., vol. 10, pp. 1295 - 1298, 2011.

[6] Elboubakraoui, M. C., Jebbor, N., Bri, S., Foshi, J.: Dielectric, Magnetic and Microwave Absorbing Properties of Structural Composites Containing Glass-Coated Amorphous Microwires at X-band Frequencies", Am J Mat Sci, 6(3): pp.67-72, 2016.

[7] Varadan, V. V. and Ro, R.:Unique retrieval of complex permittivity and permeability of dispersive materials from reflection and transmitted fields by enforcing causality, IEEE Trans. Microw. Theory Tech., vol. 55, no. 10, pp. 2224-2230, 2007.

[8] Liu, X., Zhang, L., Yin, X., Ye, F., Liu, Y. and Cheng, L.: The microstructure and electromagnetic wave absorption properties of near-stoichiometric SiC fibre, Ceram. Int., vol.43, N.3, pp. 3267-3273, 2016.

[9] Elboubakraoui, M. C., Bri S. and Foshi, J., , Electromagnetic Properties of Composites CoFeNiBSiMo, CoFeBSiCr and $\mathrm{CoMnSiB}$ in wide frequency bande, IOP Conference Series: Mater. Sci. Eng., Vol. 186, pp. 012012, 2017.

[10] Qin, F.X., and Peng, H-X.: Ferromagnetic microwires enabled multifunctional composite materials, Prog. Mater Sci., vol. 58, pp.183-259, 2013.

[11]Dinulović, M., Rašuo, B.: Dielectric properties modeling of composite materials, FME Transactions, Vol. 37 No 3, pp. 113-118, 2009.

[12] Tong, G.X. et al.: Preparation Of Light Radar Absorbing Materials With Broad Bandwidth By Mixing Iron Nanofibers With Carbonyl Iron Particles, Acta Metall. Sin., 44(8), pp.1001-1005. 2008.

[13]Liberal, I. et al.: Theoretical Modeling and Experimental Verification of the Scatterin From a Ferromagnetic Microwire", IEEE T Microw Theory, 59(3), pp. 517-526, 2011. 
[14] Baranov, S.: Radio absorption properties of amorphous microwires", Moldavian J Phys Sci; 8:332-6, 2009.

[15] Pinho, M. S., Gregori, M. L., Nunes, R. C. R. and Soares, B. G.: Performance of radar absorbing materials by waveguide measurements for $\mathrm{X}$ - and Ku-band frequencies, Eur. Polym. J., Vol. 38, No.11, pp. 2321-232, 2002.

[16]Zhang, Z., Wang, C., Zhang, Y., and Xie, J.: Microwave absorbing properties of composites filled with glass-coated Fe69Co10Si8B13 amorphous microwire, Mater. Sci. Eng. B, vol. 175, pp.233-237, 2010.

[17] Jiang, D. Y.et al.: Magnetic and microwave properties of glass-coated amorphous ferromagnetic microwires", T Nonferr Metal Soc, 17, pp.13521357, 2007.

[18]Liberal, I., Ederra, I., Gómez-Polo, C. and Labrador, A.: Theoretical Modeling and Experimental Verification of the Scattering From a Ferromagnetic Microwire", IEEE T Microw Theory, 59(3), pp.517-526, 2011.

[19] Deprota, S., Adenota, A.L., Bertina, F., Achera O.: Frequency response engineering of $\mathrm{CoFeNiBSi}$ microwires in the gigahertz range, J Magn Magn Mater, 242-245, pp.247-250, 2002.

\section{NOMENCLATURE}

\begin{tabular}{|l|l|}
\hline S11 & Reflection parameter \\
\hline S21 & Transmission parameter \\
\hline Zin & Input impedance \\
\hline FMR & Ferromagnetic resonance \\
\hline
\end{tabular}

\begin{tabular}{|l|l|}
\hline NRW & Nicholson-Ross-Weir \\
\hline TEM & Electromagnetic transmission lines \\
\hline RL & Reflection loss \\
\hline RAM & Radar Absorbent Materials \\
\hline
\end{tabular}

\section{ЕЛЕКТРОМАГНЕТНА СВОЈСТВА ПОЛИМЕРНИХ КОМПОЗИТА \\ $\mathrm{Co}_{52} \mathrm{Cr}_{22} \mathrm{Ni}_{10} \mathrm{~W}_{7,5} \mathrm{Fe}_{1,5}$ и $\mathrm{Fe}_{59} \mathrm{Cr}_{21,5} \mathrm{Ni}_{7} \mathrm{Si}_{1} \mathrm{Mn}_{10}$ Y Ku ПОJАСУ}

\section{Ш. Елбубакрауи, С. Бри, Ј. Фоши}

Електромагнетна својства полимерних композита могу се добити обрнутом нумеричком симулацијом рефлексије $S_{11}$ и трансмисије $S_{21}$. Вршено је истраживање два композита који садрже аморфну микрожицу са стакленом превлаком $\mathrm{Co}_{52} \mathrm{Cr}_{22} \mathrm{Ni}_{10} \mathrm{~W}_{7,5} \mathrm{Fe}_{1,5} \quad$ и $\quad \mathrm{Fe}_{59} \mathrm{Cr}_{21,5} \mathrm{Ni}_{7} \mathrm{Si}_{1} \mathrm{Mn}_{10} \quad$ у $\mathrm{Ku}$ појасу. Резултати показују да је имагинарни део диелектричне константе веома слаб и да се може сматрати да износи нула, што значи да не постоји диелектрични губитак. Показано је да смањење размака између инклузионих једињења има великог утицаја на магнетну резонанцију у поређењу са диелектричним одговором оба композита, који се одликује пиком феромагнетне резонанције. Такође смо приказали истраживање везано за апсорбер електромагнетног зрачења за унапред изабрани фреквентни опсег 12 - $18 \mathrm{GHz}$. Са повећањем размака микрожице минималан губитак рефлексије се прво смањује а затим повећава и помера према нижем фреквентном опсегу. 